\title{
'Do you mind if I invent you?': ethical questions in the writing of creative non-fiction
}

It is a tricky business, creative non-fiction. I have been writing a memoir investigating the life and death of my father, and the impact of that death upon my family. The memoir explores the silence surrounding the death within the particular cultural circumstances of conservative isolated Western Australia in the 1960s; how the horror and violence of the suicide and the shame of the years of mental illness that preceded it overwhelmed the capacity of those most directly affected to bring them into language. In writing the book, I have been forced to negotiate the ethical dilemmas faced when other peoples' stories intersect with one's own. Moreover I have tried to reveal rather than obscure within the fabric of the text, what I see as the inevitable intrusions of the narrator's desire; elements of invention within and on the edges of the testimony. Such a narrative strategy can only hope to engage transparently with the ethical dilemmas involved, since these cannot be neatly resolved, not even when institutional structures such as university Human Ethics Committee processes are deployed.

The narrator of my memoir was six months old when his father committed suicide; thus, he has no memory of him. Everything he knows about his father has come down to him through family and friends, but the overwhelming majority of this information has been conveyed in silence; 'enigmatically', to borrow from Laplanche (Caruth 2001: 5).

The memoir is the chronicle of an obsession. It is an obsession with what the narrator has missed, what has now and forever gone, and can only be conjured into fragile and hallucinatory existence through the production of memory and the work of fantasy.

There are, of course, precedents for this type of storytelling. Anne Brennan (2003) has written of her own ongoing obsession with the now erased Ukrainian city of Proskurov. Proskurov, childhood home of Brennan's mother's and emblem of her cultural roots, her lost past, was the site of at least two notable anti-semitic atrocities, a Soviet pogrom in 1919 and a Nazi massacre in 1943. Brennan tells us the town was razed in the Second World War, and later rebuilt by the Soviets under the new name of Khmelnitski. So now, as she says, Proskurov exists only 'as memory' (2003: 61). But her mother's memories, or, as Brennan coins them, her 're-collections' (2003: 60) are shifting and unreliable, a fluid 'set of narratives' that only deepen the enigma of the place. And, ironically, the only family photographs from Proskurov Brennan has access to are portraits taken in a photographer's studio, which show fantasy scenes of elsewhere: 'the Mediterranean terrace, complete with convenient broken column upon which the sitter can lean, or a skillfully painted backdrop of trees and flowers designed to simulate a 
civilized and thriving garden' (2003: 61). Fascinated by this place that looms so large in her family history and yet lacks any solid evidence as to ever having existed, Brennan embarks on an extensive archival search for documents, photographs, other clues, and plans a journey to the Ukraine to see for herself the new town that sits where Proskurov was. She ponders the nature of her undertaking:

Separated from my mother's story by time, history, geography, language and cultural difference, I have come to see my project as framed by lack, that poignant condition of the fragment (Brennan 2003: 61; emphasis added).

Brennan's project provides a way of contextualizing my own, in the memoir: my own digging into the archives for evidence of my father's existence; my dialogues with his closest living friends and relations aimed at bringing into language, often for the first time in such a considered way, their necessarily frail and partial memories; my production of connections and details building upon, going beyond, the evidence received. History, memory and fantasy: I am arguing that a kind of truth about the past may be enacted where these three activities of narrative production intersect, or perhaps more accurately, co-mingle. This truth makes no pretence at objectivity, since such an idea - a single uncontested objective truth about the human past - is in itself a fantasy, produced socially to support specific practices of power. As Foucault has said: "'Truth" is linked in a circular relation with systems of power which produce and sustain it, and to effects of power which it induces and which extend it' (1980: 133).

I invent my father. In inventing him I colour in the traces his absence has left on my imagination. Or as George Perec said when explaining his impulse to write about the childhood loss of his own parents: 'I write because they left in me their indelible mark, whose trace is writing' (1988: 59).

And yet, it is a project of non-fiction. I invent him but he is still, I would have you believe, my father. He is not a fictional character. I am curious to be, following Annette Kuhn's (2002: 4) lead, a detective of my own life, in traveling these borderlands between history, memory and fantasy. From a redbrick suburban archive in Perth I retrieve Brian's complete medical record detailing twenty years of mental illness. I read newspaper reports and articles from the 1950s on attitudes to homosexuality in Australia, since this becomes a subplot in the story. I discover stories of the raids on the infamous 'Lampshade Shop' of Rundle Street, Adelaide (cited French 1986: 14); of a 'bevy of boys' arrested after a straight man attempted to pick up Lana Turner in drag in Sydney's Hyde Park (cited French 1986: 22). I take diverse notes on the early history of South Australia, electric shock treatment, developments in mid-twentieth century agricultural science and so on. It is the standard eclectic research a writer might do. At the same time I examine my own memories of childhood and its mysterious silences around the subject of my absent father. And then, I mine a richer deeper vein: how Brian is remembered by his family and friends. I conduct over a dozen extended interviews, for which, since I am writing within the scholarly and institutional context of a university, I need to go through the elaborate processes of ethics clearance with which academics are now familiar. Finally and always, there is the presence of fantasy: my imaginative investment in the material or, in other words, where my desire takes me within the gaps in what I know.

So, for example, Brian (this is his name, a daggy name in my opinion, but I cannot invent another since this is one of the few facts of his identity I have always possessed) - Brian enlisted in the Navy in 1945 aged 18 and crossed 
the Nullarbor to join his training course outside Melbourne. I have a copy of an official navy document to this effect. But what form of transport did he take across that desert? Ship or train? It may have been either. Some further digging would probably reveal the answer without too much trouble. But I am too eager or lazy, my mind prefers to wander where it will, and before I know it I have gotten ahead of myself and taken an executive decision: I have put him on a train. He is already half way across that huge expanse of nothingness:

Finally, I imagine, there is a station, a solid stump of a building, propped up by a few trees. The train has almost forgotten how to stop, jolting and squealing wearily as it pulls up, and awkward with being so long and the station so short. A man stands in the door, shaded from the sun, watching the train to see how it might be different from all the other ones that have come past this way. By now, the train corridors are full of people gawking, waving, spitting onto the dirt. There's Brian; I see him pressed against the open window, sticking his head out with the rest of them.

Uncertainty grips me again as I contemplate the wanderings of my story. Here I am with an unscheduled stop in the middle of the desert. My Brian, carrying only his few light pieces of biographical detail gleaned anecdotally, has found himself surrounded by a throng of passing bit-characters. Is he planning to make his way in such manner across the continent to Melbourne, with similar scenes played out in the dining car, his sitting compartment, the station platform in Adelaide? Is he already in uniform, having signed up in Perth, or does he travel in civilian clothes until commencement of his training over East? This will surely have great bearing on the way others relate to him. If he's in uniform, they'll talk to him, ask him where he's going, and he'll feel the respect they accord him, and gain confidence in the story he relates to them, which, unlike mine, as I sometimes feel, is a perfectly respectable one: a youth, straight from school, has enlisted to fight for his country in wartime. Bravely, he ventures across the country to do his duty and cheerfully face whatever perils may await. There is neither more nor less he has to say. He is only a simple spear-carrier, an extra, one of thousands, but admirable in his naivety, adorably cute and fresh-faced in his costume, and vulnerable enough to tug the heartstrings of the older lady passengers. He'll find, this uniformed Brian, that the course of the journey announces, in a way that is both pleasurable and unsettling, a whole new version of himself, the independent young man on the cusp of life, the loyal recruit to His Majesty's forces. When the train stops in the desert, and at other times, people may turn to him as a figure of some authority. If those larrikins outside threaten to drag proceedings towards a dangerous violence, he may be expected, along with those other men in uniform almost certainly dotted like him through the train, to assert some order. This, the idea of having to physically confront the offenders, is a frankly terrifying prospect that brings him face to face with the vision of his father shaking him by his collar ... the disgust in his eyes ... The ladies around Brian on the train have no idea their young matinee idol is a coward and a bedwetter. The uniform is a brittle masquerade, and beneath its creases, insignia and polish his flesh is soft and weak. He sees himself reflected in his father's eyes: a puppy, not a man.

On the other hand, the Brian not yet uniformed travels incognito, an intriguing stranger, quiet, absorbed in his books. He's perfectly polite but unforthcoming, shy most likely, attracting as little attention as possible. For some he's almost a ghost; they barely see him - after three days sitting next to him on a train would have difficulty giving evidence as to his appearance, let alone his identity. Others watch him from the corner of their eye and 
daydream his possible lives, where he's come from, where he's going all alone. Can he really be as young as he looks?

Now he is on the train I have grown attached to him there. What will I do if I find out after all it was a ship he travelled on? Do I have an ethical duty to scrap the scene, or recast it in a nautical setting? Perhaps what I have, at least, is an ethical duty to make clear when I am or am not fabulizing - to make clear within the weave of the writing that this train is now one I have imagined.

My feeling is that Brian, being long-dead, cannot be affected by what I write, how I invent him. I am interested then when a philosopher friend tells me he thinks the central ethical issue facing me is whether my father would be happy with what I am doing, whether I am doing justice to his memory. It has never occurred to me to worry about Brian's point of view. Why is this? Perhaps because I think that having departed so abruptly he is no position to argue? But, attempting to be more grown-up about it: from all I have uncovered about him, it seems he was constantly searching to discover for himself what was wrong with his mind. Brian too sought to be a detective of his own life, even if tragically he remained unable to solve his case - except in the negative, as it were.

But what about all the other characters in the story who live on? What are the ethical issues I face in writing about living people in a memoir? My argument, to begin with, is that there is no way I can purport to represent them 'objectively', but that on the other hand I have a responsibility to represent them truthfully - that is, not to misrepresent them - especially since my story is built in no small part on their testimonies to me given in good faith. But if I think it through further, what I actually believe is that, given fact and fiction cannot be kept neatly quarantined where memories are concerned, my responsibility is to represent the truth of this very impossibility of a singular 'truthful' representation. My responsibility, moreover, is to not erase the traces of my own partiality, my own desire in the case I am attempting to 'solve'.

As my project began as part of a Ph.D. through the University of Melbourne, I needed to gain ethics clearance from the Human Research Ethics Committee of the University in order to conduct interviews with family members and friends of my father. I was told that this was the first time a student at The University of Melbourne had applied for ethics clearance for the creative writing component of a higher degree.

From conversations with other postgraduate students and academics it is clear that complying with the bureaucratic requirements of Human Ethics Committee application processes is often considered to be about as enticing as dental root canal surgery. Nevertheless, although we might mutter that these ethics approval processes have become standard practice at universities merely in response to institutional fears of litigation, serious ethical questions raised in the conduct of a project such as mine do need to be considered. The Human Ethics Committee process - despite what some may see as the shortcomings of its 'one-size-fits-all' approach across the academy - provides a framework for so doing.

For medical or psychology researchers the humans involved in their research may be asked to undertake a medical trial or a psychological test. It is clear that such participants need to be granted the right to what is known as 'informed consent'. As the 2007 'National Statement on Ethical Conduct' published by the NHMRC, ARC and AVCC elaborates in its preamble, the 
appallingly inhumane human experiments undertaken in the name of science by the Nazis prompted the development of the Nuremberg Code defining principles for what henceforth would be agreed permissible in medical experiments.

But what were the risks involved for the human subjects asked to participate in my research? I am asking them, not to take an experimental medication or suchlike, but rather to remember and to tell stories - bearing in mind that these memories and stories pertain to the potentially distressing history of the mental illness and suicide of a someone who was once very close to them: a friend, brother, father, husband.

Central to the concept of informed consent is the provision of information as to what the point of the research is, what the participation of the individual in that research requires them to do, and how the data gathered from their participation will be used, or 'processed' by the researcher. I was required to write, and to give to each potential 'researchee', what is called a 'Plain Language Statement'.

My Plain Language Statement said, in part:

The aim of this study is to investigate, through the medium of creative writing, an autobiographical family trauma, surrounding the mental illness and suicide of David Carlin's father, Brian. Should you agree to participate, you would be asked to contribute to this by participating in an interview or series of interviews, conducted by David Carlin.

Note: Please be advised that your participation in this study is completely voluntary. Should you wish to withdraw at any stage, or to withdraw any unprocessed data you have supplied, we want to make it clear that you are absolutely free to do so without prejudice. (Carlin 2004)

'Unprocessed data' - how on earth, the poets might wonder, might such a sterilized term translate into the notably unscientific realm of creative writing? What is the nature of the 'processing' that takes place, when this data, being a quantum of memories and stories, verbal images, filters through the mind of a writer and emerges, condensed, collaged, juxtaposed within an unfolding narrative? When does such processing begin? Surely during the interviews itself, when even as the interviewee is testifying as to their memories and impressions the writer cannot help but be supplying mental images to accompany the stories heard; cannot help but be considering, consciously or not, the affects that play out in the interviewee's face and body as they tell their story. Given this, the promise to withdraw any 'unprocessed data', which is a standard phrase in such Ethics process documents, remains, thankfully, untested.

To quote again from the plain language statement:

The material gathered from the interviews will be used to feed directly or indirectly into the process of creative writing for the project. Information you provide may or may not be directly attributed to you within the text created. It is possible that the circumstances (location, etc) of the interview may also be described. (Carlin 2004; emphasis added)

You see how vague and slippery this language is: 'feed directly or indirectly'. But could it be otherwise? 
At one point in the memoir, I wrote:

My sister Wendy called last night, from England. She remembers, from the age of six, having come to Perth to stay at Scarborough with our grandmother for months at a time, whilst our father was in hospital. Scarborough was at that time a quiet seaside suburb, a few fingers of housing stretching out into the scrubby sand dunes. Wendy remembers the Kennedy death from Scarborough - seeing the headline on a newspaper lying in the front of the car, while the adult went to buy a Choc-Wedge. A scorching day, the ocean glassy, not a whiff of the sea-breeze ...

Another family member joked with me after he had read the first draft of the memoir: 'I suppose you might now write down our conversation just now and put that in the book as well - "x called me on the phone last night and discussed his feelings about how he was represented in the manuscript ..."' As if his any interaction with me might now be fair game, grist for the mill. Like all jokes this one contained an element of truth. I had to reassure him this would not be the case; that I had no interest in an endless hall of mirrors of reported conversations - but what if I had? I could see his point - and, when writing autobiographically about lives and memories, one can see the difficulty of drawing neat boundaries around what is covered, for instance, by Ethics consent.

I asked another interviewee, upon reading the draft, whether he felt it painted an accurate picture of the family. Apart from some minor quibbles here and there, he said, it was all 'very true'. But, he added, he felt as if his family's front door had been left wide open so that everyone walking by in the street could see right in. 'Exposed', he said he felt. Do I betray his trust still further by reporting this here?

I wrote in the memoir:

All this time, [Tom, Brian's father] remained distant from his sons. When they encountered him it was across the silent dinner table or at the other end of the razor strop. Discipline and punishment in this family played out in a cruel and protracted ritual, albeit one perhaps common enough in its day. First would come the misdemeanour, Brian or one of his brothers crossing a line, behaving badly. This was as witnessed and adjudged by Doris from her position at the frontline of the children's behaviour, where Tom was invariably absent. But Doris would never herself mete out punishment for crimes committed by the boys; her role was merely to deliver the injunction: wait til your father gets home. The appointed hour would come later the same day, or as much as a week or a month afterwards, depending on Tom's schedule. Doris would report the summary of offences, and Tom, the dutiful executioner, march off to the bathroom for the strop. The sentenced child endured the humiliation of pants dropped to the ankles, then the pain of lashings on tender flesh. Meanwhile Doris fled to the bedroom to hide her head under the pillow, not to hear the anguished cries of her poor baby.

'In autobiography', writes Nancy Miller (2002: 210), 'the acts - performed and witnessed - that might seem to beg not to be revealed are the very ones that produce writing. 'Secret knowledge', she continues, 'becomes public shame ... As you tell the secrets of others, and violate family codes, you separate yourself from their power over you, even as you return to them in memory' (Miller 2002: 210). By definition the memoir project I have been writing has been carved from shame, as it were, since it seeks to talk about what was held taboo, a family secret. And even if all involved can agree in principle it is a 
good thing for the story to be told, nevertheless shame itself may cling on doggedly.

Do you mind if I invent you? Do you mind if I lay bare your secrets? It is a big ask. But what if you do mind? Will that stop me? The writer is determined to stubbornly transgress, to bear witness, or to paraphrase Miller, 'to repair the irreparable in [their child self's] past' (2002: 211) - is there a necessary selfishness involved? These ethical questions, it seems, will never be easy to resolve.

\section{List of works cited}

Brennan, A 2003 'Re-collecting Proskurov', in J. Bennett \& R. Kennedy (eds), World memory, Basingstoke: Palgrave Macmillan, 59-68 return to text

Carlin, D 2004 'Project statement "leaves falling from trees"', unpublished, University of Melbourne return to text

Carlin, D 2010 (forthcoming) Our Father Who Wasn't There, Melbourne: Scribe

Caruth, C 2001 'An interview with Jean Laplanche', Postmodern culture 11.2, http://muse.jhu.edu/journals/pmc/v011/11.2caruth.html (accessed 3 May 2008) return to text

Foucault, M 1980 Power/knowledge: selected interviews and other writings, 1972-1977, Brighton: Harvester Press return to text

French, R 1986 Gays between the broadsheets: an annotated list of Australian media references on homosexuality, 1948-1980, Darlinghurst: Gay History Project return to text

Kuhn, A 2002 Family secrets: acts of memory and imagination, New York, London: Verso return to text

Miller, N 2002 'Memory stains: Annie Ernaux's shame', in N. Miller and J. Tougaw (eds) Extremities: trauma, testimony, and community, Urbana: University of Illinois Press, 197-212 return to text

N.H.M.R.C., A.R.C., and A.V.C.C. 2007, National statement on ethical conduct in human research, Canberra: Australian Government return to text

Perec, G 1988 W, or, the memory of childhood, London: Collins Harvill return to text

David Carlin is a writer, film-maker and Lecturer in Media at RMIT University's School of Applied Communication. His plays, short films and documentaries have been variously performed and screened internationally, and he has published most recently in Overland and Senses of Cinema. The memoir excerpted in this article formed part of his recently completed PhD, and is to be published by Scribe.

TEXT Special Issue No 5 The Art of the Real

April 2009

http://www.textjournal.com.au

Editors: Keri Glastonbury and Ros Smith

General Editors: Nigel Krauth \& Jen Webb

Text@griffith.edu.au 